\title{
Tropospheric warming over the North Indian Ocean caused by the South Asian anthropogenic aerosols: possible implications
}

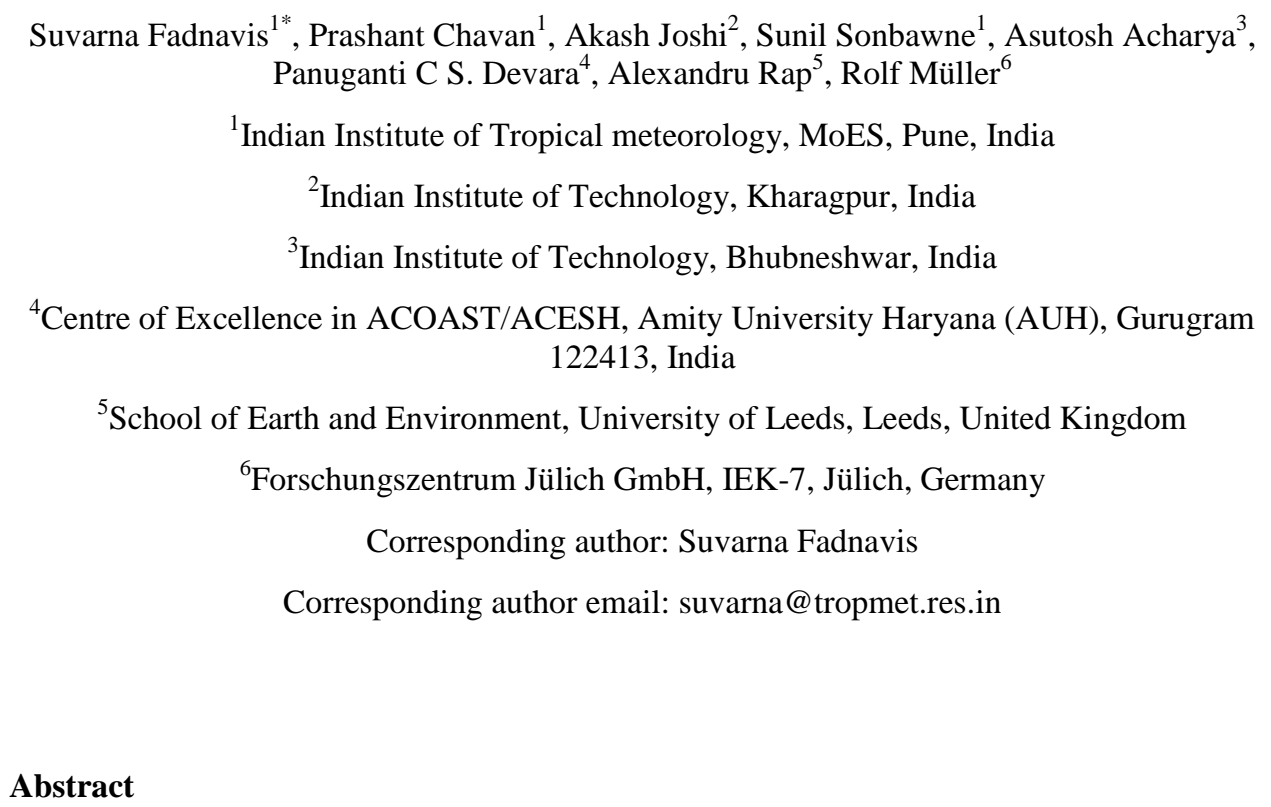
stratosphere (UTLS) by the convection over the Arabian Sea and Bay of Bengal. In the UTLS, they are further transported to the southern hemisphere $\left(30-40^{\circ} \mathrm{S}\right)$ and downward into the troposphere by the secondary circulation induced by the aerosol changes. The carbonaceous aerosols are also transported to the Arctic and Antarctic producing local heating $\left(0.002-0.05 \mathrm{~K} \mathrm{~d}^{-1}\right)$. 
29 The presence of anthropogenic aerosols causes negative radiative forcing (RF) at the TOA (-

$\left.30 \quad 0.90 \pm 0.089 \mathrm{~W} \mathrm{~m}^{-2}\right)$ and surface $\left(-5.87 \pm 0.31 \mathrm{~W} \mathrm{~m}^{-2}\right)$ and atmospheric warming $(+4.96 \pm 0.24 \mathrm{~W}$

$\left.31 \mathrm{~m}^{-2}\right)$ over South Asia $\left(60^{\circ} \mathrm{E}-90^{\circ} \mathrm{E}, 8^{\circ} \mathrm{N}-23^{\circ} \mathrm{N}\right)$, except over the Indo-Gangetic plain

$32\left(75^{\circ} \mathrm{E}-83^{\circ} \mathrm{E}, 23^{\circ} \mathrm{N}-30^{\circ} \mathrm{N}\right)$ where $\mathrm{RF}$ at the TOA is positive $\left(+1.27 \pm 0.16 \mathrm{~W} \mathrm{~m}^{-2}\right)$ due to

33 large concentrations of absorbing aerosols. The carbonaceous aerosols produced in-

34 atmospheric heating along the aerosol column extending from the boundary layer to the

35 UTLS $\left(0.01\right.$ to $\left.0.3 \mathrm{~K} \mathrm{~d}^{-1}\right)$ and in the stratosphere globally $\left(0.002\right.$ to $\left.0.012 \mathrm{~K} \mathrm{~d}^{-1}\right)$. The heating of the troposphere increases water vapor concentrations, which are then transported from

37 highly convective region (i.e. the Arabian Sea) to the UTLS (increasing water vapor by 0.02 -

$380.06 \mathrm{ppmv})$.

39 Keywords: South Asian Anthropogenic aerosols; warming over the Arabian Sea; transport of 40 aerosols and water vapor to the UTLS in spring. 


\section{Introduction}

Understanding the variability of anthropogenic aerosol loading over the North Indian Ocean is of utmost importance since (1) it regulates the Asian hydrological cycle via modulating atmospheric convection, heating rates, and moisture transport (Ramanathan et al. 2005; Corrigan et al., 2008; Budhavant et al., 2018, Meehl et al., 2008), and (2) it leads to adverse impacts on marine ecosystems (Mahowald et al., 2018; Collins et al., 2019). Several observations indicate that the aerosol loading over the North Indian Ocean during the spring season is strongly influenced by South Asian aerosols. Aircraft measurements during the Indian Ocean Experiment (INDOEX) (February-March 1999) showed the presence of a thick layer (surface to $3.2 \mathrm{~km}$ ) of anthropogenic aerosols (BC 14\%, sulfate $34 \%$, ammonium 11 \%) over the North Indian Ocean (Dickerson et al., 2002; Mayol-Bracero et al., 2002) with sources over South Asia. Several other in situ observations, e.g. over the Maldives during November 2014 - March 2015, show that air masses arising from the Indo-Gangetic Plain contain very high amounts $(97 \%)$ of the elemental carbon in the fine mode. Other anthropogenic species such as organic carbon, non-sea-salt, potassium, and ammonium (7095\%) were also observed in the fine mode (Bhudhvant et al., 2018). Observations from the Geosphere-Biosphere Programme over the Bay of Bengal during spring (March 2016) also show abundant anthropogenic aerosols (sulfate and nitrate) having sources over the IndoGangetic plain (Nair et al., 2017).

The aerosol loading over South Asia has been increasing at an alarming rate (rate of increase in AOD 0.004 per year during 1988 - 2013) (Babu et al., 2013). For the last two decades, the AOD increase (by $12 \%$ ) over south Asia has been attributed to the strong increase in anthropogenic aerosols (sulfate, black carbon, and organic carbon), while natural aerosol remained unchanged (Ramachandran et al., 2020a). The major sources of 
anthropogenic aerosols are the combustion of domestic fuels, industrial emissions, transportation, and open burning (Paliwal et al., 2016). The growth of the economy of India led to a $41 \%$ increase in BC and $35 \%$ in OC from 2000 to 2010 ( $\mathrm{Lu}$ et al., 2011). The emissions of sulfur dioxide $\left(\mathrm{SO}_{2}\right)$ which leads to the production of sulfate aerosols have doubled during 2006 - 2017 (Fadnavis et al., 2019). Figure 1 a-c shows the annual mean emission of BC, OC, and sulfate aerosols over South Asia in 2016, with high emissions over the Indo-Gangetic Plain (BC 7E-12 - 17E-12 $\mathrm{Kg} \mathrm{m}^{-2} \mathrm{~S}^{-1}$, OC: $25 \mathrm{E}-12-70 \mathrm{E}-12 \mathrm{Kg} \mathrm{m}^{-2} \mathrm{~S}^{-1}$, sulfate: $2 \mathrm{E}-12-5 \mathrm{E}-12 \mathrm{Kg} \mathrm{m}^{-2} \mathrm{~S}^{-1}$ ). Higher amounts of aerosols over the Indo-Gangetic Plain are associated with densely populated regions and industrial and vehicular emissions (Karambelas et al., 2018, Fadnavis et al., 2019). Past studies also show substantially higher amounts of aerosols over North India compared to rest of the Indian region (Ramachandran et al., 2020b, Fadnavis et al., 2013, 2017a, 2017b). Over the Indo-Gangetic plain, these emissions show a peak in spring (Fig. 1d), with increases for BC of $0-3 \%$, OC $0-8.7 \%$, and sulfate $0-0.2 \%$, compared to annual means. This peak in emissions in spring is to a large extent driven by springtime agricultural crop burning and biomass burning activity (Chavan et al., 2021).

While the presence of sulfate aerosols lead to a cooling of the atmosphere below due to their strong scattering properties, carbonaceous aerosols produce atmospheric warming via absorption of solar radiation (Fadnavis et al., 2019, Penner et al., 1998). Previous studies showed that the doubling of carbonaceous aerosols loading over Asia $\left(10^{\circ} \mathrm{S}-50^{\circ} \mathrm{N}, 65^{\circ} \mathrm{E}-\right.$ $155^{\circ} \mathrm{E}$ ) led to significant atmospheric warming (in-atmospheric RF $5.11 \mathrm{~W} \mathrm{~m}{ }^{-2}$, Fadnavis et al. 2017b). 
(a) BC emission annual mean

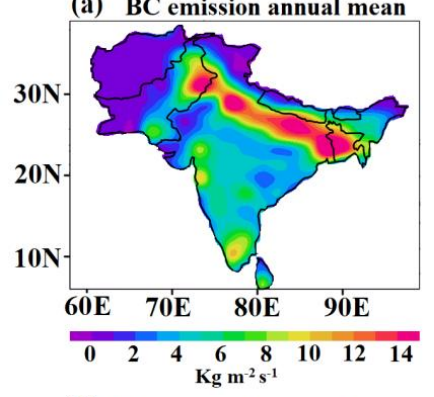

94

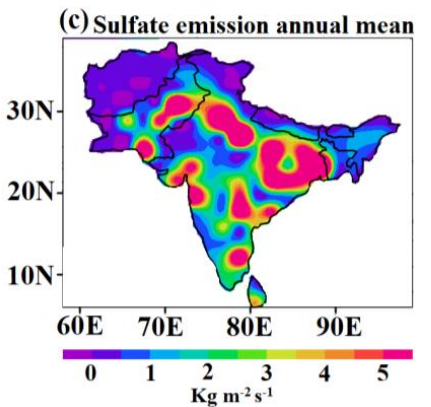
$\left(23^{\circ}-30^{\circ} \mathrm{N}, 78-90^{\circ} \mathrm{E}\right)$.
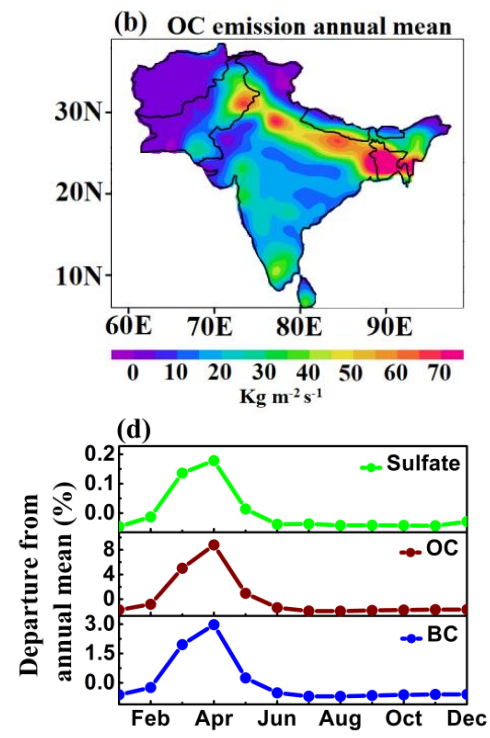

Figure 1: Spatial distribution of year 2016 annual mean total emission $\left(\mathrm{kg} \mathrm{m}^{-2} \mathrm{~S}^{-1}\right)$ of (a) BC, (b) OC, (c) Sulfate aerosols, (d) time series of monthly departure from annual mean total emissions (\%) of BC, OC, and Sulfate aerosols averaged over Indo-Gangetic plain

During spring, the prevailing convective instability over the Bay of Bengal and the Arabian Sea transports aerosol from the boundary layer to the upper troposphere (Romatschke and Houze, 2011). Airborne observations during winter and spring, e.g. the Civil Aircraft for Regular Investigation of the Atmosphere Based on an Instrument Container (CARIBIC) in March 1999 and January 2001 (Papaspiropoulos et al., 2002), and the Indian Ocean Experiment (INDOEX) in February-March 1999 show elevated aerosol amounts near 8-12 km over the Indian Ocean and South Asia (De Reus et al., 2001). Recently, using a set of model simulations, Chavan et al., (2021) reported the transport of biomass burning aerosols to the upper troposphere by the convection in spring 2013. 
Here, we investigate the source of the very large aerosol loading over the Arabian Sea during spring. These aerosols produce atmospheric warming leading to enhanced water vapor that is transported to the UTLS. Once in the lower stratosphere, the water vapour is transported globally, which has implications for tropospheric temperatures and possibly stratospheric ozone. For this purpose, we performed a series of five simulations using the ECHAM6-HAMMOZ model for changes in anthropogenic aerosol over South Asia.

\section{Model simulations and satellite data}

\subsection{ECHAM6-HAMMOZ experimental set-up}

We used the state of art ECHAM6-HAM aerosol-chemistry-climate model. It comprises of the general circulation module ECHAM6, coupled to the aerosol and cloud microphysics module HAM (Stier et al., 2005; Tegen et al., 2019). HAM predicts the nucleation, growth, evolution, and sinks of sulfate, black carbon (BC), particulate organic matter (POM), sea salt (SS), and mineral dust (DU) aerosols. The size distribution of the aerosol population is described by seven log-normal modes with prescribed variance as in the M7 aerosol module (Stier et al., 2005; Zhang et al., 2012). Moreover, HAM explicitly simulates the impact of aerosol species on cloud droplet and ice crystal formation. Aerosol particles can act as cloud condensation nuclei or ice-nucleating particles. Other relevant cloud microphysical processes such as evaporation of cloud droplets, sublimation of ice crystals, ice crystal sedimentation, and detrainment of ice crystals from convective cloud tops are simulated interactively (Neubauer et al., 2014). The anthropogenic and fire emissions of sulfate, black carbon (BC), and organic carbon (OC) are based on the AEROCOM-ACCMIP-II emission inventory. Other details of the model and emissions are reported by Fadnavis et al. (2017a, 2019, 2021a, b). 
134 The model simulations are performed at the T63 spectral resolution corresponding to $1351.875^{\circ} \times 1.875^{\circ}$ in the horizontal dimension, while the vertical resolution is described by 47 136 hybrid $\sigma-$ p levels from the surface up to $0.01 \mathrm{hPa}$ (approx. $80 \mathrm{~km}$ ). The simulations have been carried out at a time step of $20 \mathrm{~min}$. Monthly varying Atmospheric Model Intercomparison Project (AMIP) sea surface temperature (SST) and sea ice cover (SIC) (Taylor et al., 2000) were used as lower boundary conditions.

We performed five model experiments: (1) a control (CTL) simulation where all aerosol emissions are included and four perturbed experiments where (2) all anthropogenic aerosol emissions (black carbon, organic carbon, and sulfate) are switched off over South Asia (75 $100^{\circ} \mathrm{E}, 8-40^{\circ} \mathrm{N}$, see Fig. 1) during the study period (2001 - 2016) (referred to as Aerooff), (3) only anthropogenic black carbon emissions (BC) switched off during the study period, (BCoff), (4) only anthropogenic organic carbon (OC) emissions switched off (OCoff) during the study period, and (5) only anthropogenic sulfate aerosol emissions switched off (Suloff) during the study period (see Table 1). All simulations were performed from 1 January 2001 to December 2016 from stabilized initial fields created after a model integration for one year. Dust emission parameterization is the same in all the simulations and is based on Tegen et al. (2002). The analysis is performed for spring (March - May) averaged for the period 2001 2016. We compare the CTL with Aerooff, BCoff, OCoff, and Suloff simulations to understand the impact of south Asian anthropogenic aerosols over the Indian region and surrounding ocean. 
Table -1: Details of eECHAM6-HAMMOZ model simulations performed in this study.

\begin{tabular}{|l|l|l|l|}
\hline $\begin{array}{l}\text { Experiment } \\
\text { name }\end{array}$ & Duration & Aerosol species on/off & Boundary conditions \\
\hline CTL & $2001-2016$ & $\begin{array}{l}\text { All aerosols species globally, as } \\
\text { per AEROCOM-ACCMIP-II } \\
\text { emission inventory. }\end{array}$ & $\begin{array}{l}\text { AMIP Sea surface } \\
\text { temperature and sea } \\
\text { ice concentration. }\end{array}$ \\
\hline Aerooff & $2001-2016$ & $\begin{array}{l}\text { Anthropogenic BC, OC, and } \\
\text { sulfate aerosols switch off over } \\
\text { South Asia during 2001-2016. }\end{array}$ & $\begin{array}{l}\text { AMIP Sea surface } \\
\text { temperature and sea } \\
\text { ice concentration. }\end{array}$ \\
\hline BCoff & $2001-2016$ & $\begin{array}{l}\text { Anthropogenic BC aerosols } \\
\text { switch off over South Asia } \\
\text { during 2001-2016. }\end{array}$ & $\begin{array}{l}\text { AMIP Sea surface } \\
\text { temperature and sea } \\
\text { ice concentration. }\end{array}$ \\
\hline OCoff & $2001-2016$ & $\begin{array}{l}\text { Anthropogenic OC aerosols } \\
\text { switch off over South Asia } \\
\text { during 2001-2016. }\end{array}$ & $\begin{array}{l}\text { AMIP Sea surface } \\
\text { temperature and sea } \\
\text { ice concentration. }\end{array}$ \\
\hline Suloff & $2001-2016$ & $\begin{array}{l}\text { Anthropogenic sulfate aerosols } \\
\text { switch off over South Asia } \\
\text { during 2001 - 2016. }\end{array}$ & $\begin{array}{l}\text { AMIP Sea surface } \\
\text { temperature and sea } \\
\text { ice concentration. }\end{array}$ \\
\hline
\end{tabular}

2.2 AOD satellite observations

In this study we use the last fifteen years $(2001-2016)$ of aerosol optical depth at $0.55 \mu \mathrm{m}$ (AOD) obtained from the Moderate Resolution Imaging Spectroradiometer (MODIS) instrument onboard the NASA EOS Terra satellite. The MODIS instrument measure radiance in 36 spectral channels at spatial resolution ranging from $250 \mathrm{~m}$ to $1 \mathrm{~km}$ with a $2300 \mathrm{~km}$ wide swath, allowing for almost daily global coverage. Terra MODIS (MOD08_M3 V6.1) AOD aerosol products are retrieved using the Deep Blue (DB) algorithm (Mhawish et al., 2019). The algorithm calculates the column aerosol loading at $0.55 \mu \mathrm{m}$ over land and ocean. The AOD data from MODIS Terra can be downloaded from https://ladsweb.modaps.eosdis.nasa.gov/archive/allData/61/MODATML2/ 
AOD data from the Multi-angle Imaging Spectro-Radiometer (MISR) for the same period as

170 MODIS (2001 - 2016) is also used for model evaluation. The MISR sensor onboard the Terra

171 satellite has been operational since 1999. It makes measurements at four spectral bands

172 centered at $443 \mathrm{~nm}, 555 \mathrm{~nm}, 670 \mathrm{~nm}$, and $865 \mathrm{~nm}$ (Diner et al., 2008). In this study we used,

173 level 3 (MIL3MAE_v4) monthly mean aerosol optical depth at $555 \mathrm{~nm}$ wavelength at spatial

174 resolution $0.5^{\circ} \times 0.5^{\circ}$. The MISR AOD data is available for download at

175 https://misr.jpl.nasa.gov/getData/accessData/.

\subsection{Model evaluation}

We evaluate model performance by comparing simulated AOD (from CTL simulations) with MISR and MODIS data for the spring season. The model simulations show high amounts of AOD over the Indo-Gangetic plain, Myanmar, and East Asia, consistent with MODIS and MISR observations, despite quantitative differences (Fig. 2). Compared to observations, the model underestimates AOD over the Indo-Gangetic plain (model: 0.15 to 0.4, MODIS: 0.4 to 0.8, MISR: 0.3 to 0.5 ) and overestimates AOD over East Asia (model: 0.6 to 1.4 , MODIS: 0.4 to 1.2 , MISR: 0.2 to 0.5 ). Over the Myanmar region, the model underestimates AOD in comparison to MODIS, but overestimates it in comparison to MISR (model: 0.15 to 0.5 , MODIS: 0.3 to 0.8 MISR: 0.15 to 0.3 ). There are differences among satellite observations and between the model and observations. The differences are due to uncertainties in the model due to model transport processes, emission inventory, and parametrisations (Fadnavis et al. 2014, 2015, 2018, 2019) and there are uncertainties in satellite measurements (Bibi et al., 2015). With model biases present in both the CTL and the perturbed simulations, investigating anomalies removes some of the model bias. In the past Fadnavis et al. (2018, 2019, 2020, 2021a,b) reported model evaluations for AOD, absorbing aerosol index, precipitation, mixing ratio of black carbon aerosol and cloud ice 

model.
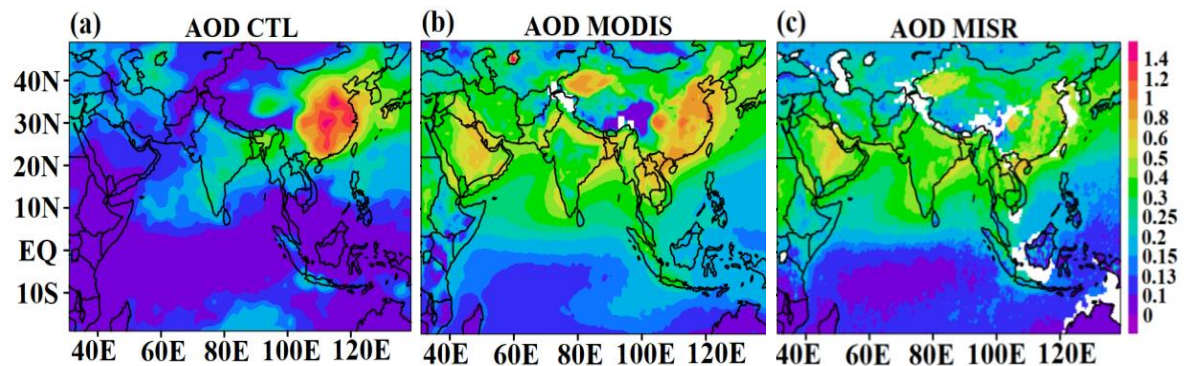

Figure 2: Spatial distribution of AOD average for the spring season during 2001 - 2016, from (a) ECHAM6-HAMMOZ CTL simulations, (b) MODIS measurements average for the spring season during 2001 - 2016, (c) MISR measurement average for the spring season during $2032001-2016$.

\section{Results and discussions}

\subsection{Transport of South Asian aerosols to the North Indian Ocean}

The spatial distribution of AOD anomalies from the Aerooff simulation shows positive anomalies of AOD extending from South Asia to the Arabian Sea and the North Bay of Bengal $\left(10-20^{\circ} \mathrm{N}\right)($ Fig. 3a). The wind vectors indicate that these are transported from the Indo-Gangetic plain to the Arabian Sea and the Bay of Bengal. The transported aerosols enhanced the AOD by $0.18-0.8(30-80 \%)$ over the North Bay of Bengal and by $0.02-0.12$ (20 - $60 \%$ ) over the Arabian Sea. This is consistent with previous studies where 50 - $60 \%$ enhancements in the AOD over the tropical Indian Ocean due to anthropogenic aerosols have been reported (Satheesh et al. 1999; Jose et al. 2020). Chemical analysis of aerosols observed over the south-eastern coastal Arabian Sea also shows the dominance of anthropogenic aerosols having sources over the Indian region (73\%) (Aswini et al., 2020). Analysis of MODIS satellite observations (2003 - 2017) likewise shows that anthropogenic sources contributed $\sim 60-70 \%$ to the aerosol loading over the east coast and west coast of India (Jose 

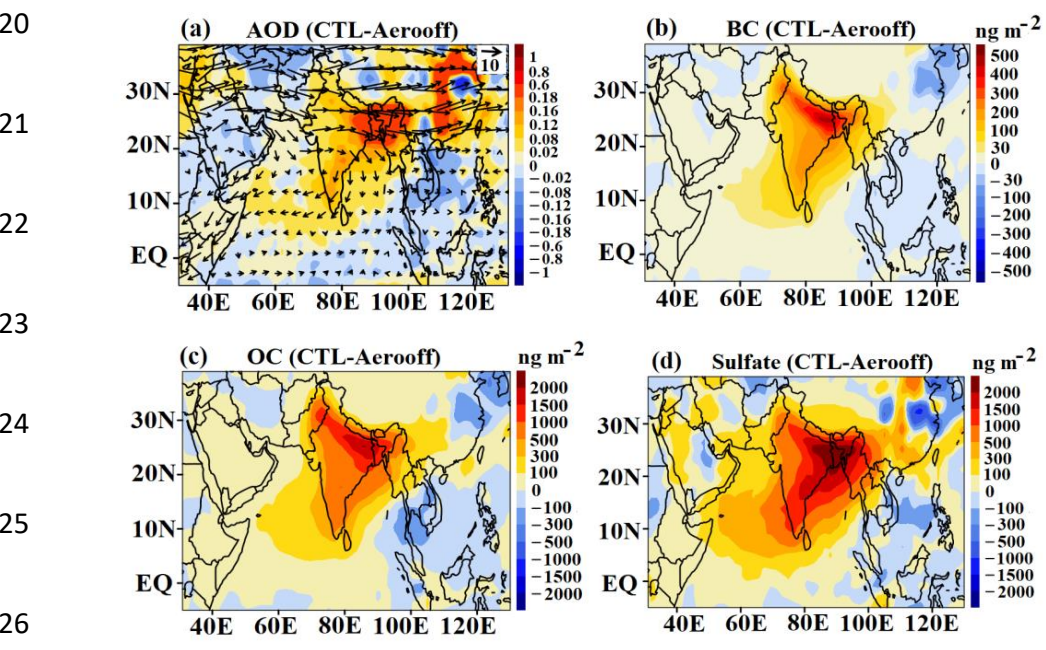

Figure 3: Spatial distribution of (a) AOD anomalies averaged for spring during 2001 2016 (CTL - Aerooff), and anomalies of tropospheric column of (b) BC, (c) OC, and (d) sulfate aerosols $\left(\mathrm{ng} \mathrm{m}^{-2}\right)$ (CTL-Aerooff). The vectors in Fig.1a indicate winds $\left(\mathrm{m} \mathrm{s}^{-1}\right)$ at $850 \mathrm{hPa}$.

The distribution of anomalies in the tropospheric column of $\mathrm{BC}, \mathrm{OC}$, and sulfate aerosols also indicates that these aerosols are transported from South Asia to the Bay of Bengal and the Arabian Sea (Fig. 3b-d). Enhancement of sulfate and OC aerosol $\left(100-2000 \mathrm{ng} \mathrm{m}^{-2}\right)$ is higher than $\mathrm{BC}\left(100-500 \mathrm{ng} \mathrm{m}^{-2}\right)$ over the South Asian region (Fig. 3b-d). The total carbonaceous aerosol (BC and $\mathrm{OC}$ together) dominates over the sulfate aerosols. These anthropogenic aerosols over the tropical Indian Ocean affect the radiation budget and cloud cover over the Indian Ocean (Satheesh et al. 1999; McFarquhar and Wang 2006). 


\subsection{Radiative forcing}

The anthropogenic aerosols over the tropical Indian Ocean affect the radiation budget and cloud cover (McFarquhar and Wang 2006). Here, we discuss the impact of south Asian anthropogenic aerosols on radiative forcing (RF). Figures 4a-c show anomalies in net radiative forcing $(\mathrm{RF})$ at the TOA, surface, and in-atmosphere (TOA - surface) for Aerooff simulations (CTL - Aerooff). The anthropogenic aerosols have produced a cooling at the TOA (except over the Indo-Gangetic plain) and surface (see Fig. 4a-b). The simulated RF values over the Arabian Sea $\left(55-70^{\circ} \mathrm{E}, 8-20^{\circ} \mathrm{N}\right)$, Bay of Bengal $\left(88-92^{\circ} \mathrm{E}, 12-20^{\circ} \mathrm{N}\right)$, and Indo-Gangetic Plain $\left(75-83^{\circ} \mathrm{E}, 26-30^{\circ} \mathrm{N}\right)$ are tabulated in Table-S1. The RF estimates show that aerosols have produced significant cooling at the TOA and surface over the Arabian Sea (TOA: $-0.72 \pm 0.14 \mathrm{~W} \mathrm{~m}^{-2}$, surface:-3.0 $\pm 0.28 \mathrm{~W} \mathrm{~m}^{-2}$ ), Bay of Bengal (TOA:$1.24 \pm 0.15 \mathrm{Wm}^{-2}$, surface: $-5.14 \pm 0.44 \mathrm{~W} \mathrm{~m}^{-2}$ ), and in-atmospheric warming over the above regions (Arabian Sea $+2.27 \pm 0.19 \mathrm{~W} \mathrm{~m}^{-2}$; Bay of Bengal: $+3.89 \pm 0.30 \mathrm{~W} \mathrm{~m}^{-2}$ ) $($ Fig. $4 \mathrm{c})$. The Indo Gangetic Plain shows positive anomalies of $\mathrm{RF}$ at the TOA $\left(+1.27 \pm 0.16 \mathrm{Wm}^{-2}\right)$, negative at the surface $\left(-11.16 \pm 0.50 \mathrm{Wm}^{-2}\right)$, and atmospheric warming of $+12.44 \pm 0.42 \mathrm{~W} \mathrm{~m}^{-}$ ${ }^{2}$. In agreement with our results, several previous studies have reported negative RF at the surface and TOA, and atmospheric warming over the north Indian Ocean caused by enhanced anthropogenic aerosol. For example, Pathak et al. (2020) reported negative aerosol RF at the TOA ( -2 to $-4 \mathrm{~W} \mathrm{~m}^{-2}$ ) over the Bay of Bengal and the Arabian Sea during spring 2009 - 2013. Reddy et al., (2004) estimated positive in-atmosphere RF over the North Indian Ocean (+25 $\mathrm{W} \mathrm{m}^{-2}$ ). The aerosol radiative forcing estimated from satellite measurements (January to March 1999) over the north Indian ocean is also negative at TOA (-4 and $\left.-14 \mathrm{~W} \mathrm{~m}^{-2}\right)$ and surface (-12 to $-42 \mathrm{~W} \mathrm{~m}^{-2}$ ) (Satheesh and Ramanathan 2000; Rajeev and Ramanathan et al, 2001). The clear sky aerosol direct radiative forcing estimated from measurements during the INDOEX experiment (January to March in 1999) over the north Indian Ocean also show 
similar results (TOA: $-7 \mathrm{~W} \mathrm{~m}^{-2}$, surface: $-23 \mathrm{~W} \mathrm{~m}^{-2}$, and in-atmosphere: $+16 \mathrm{~W} \mathrm{~m}^{-2}$ )

(Ramanathan et al. 2001). These studies attribute positive in-atmospheric radiative forcing to absorbing aerosols (especially black carbon) that lead to heating of the atmosphere (Rajeev and Ramanathan 2001; Satheesh et al 2002).

Analysis of the perturbed model experiments indicates that anthropogenic BC aerosols (Fig. 4d-f) have produced a warming at the TOA (Arabian Sea: $1.24 \pm 0.13 \mathrm{~W} \mathrm{~m}^{-2}$, Bay of Bengal: $1.54 \pm 0.26 \mathrm{~W} \mathrm{~m}^{-2}$, Indo-Gangetic Plain: $4.33 \pm 0.17 \mathrm{~W} \mathrm{~m}^{-2}$ ) and cooling at the surface (Arabian Sea: $-2.56 \pm 0.25 \mathrm{~W} \mathrm{~m}^{-2}$, Bay of Bengal: $-3.70 \pm 0.49 \mathrm{~W} \mathrm{~m}^{-2}$, Indo-Gangetic Plain:-9.27 $\pm 0.37 \mathrm{~W} \mathrm{~m}^{-2}$ ). OC (Fig. 4g-i) and sulfate (Fig. 4j-1) aerosols have produced significant cooling at the TOA (OC: $-0.21 \pm 0.13$ to $-0.44 \pm 0.15 \mathrm{~W} \mathrm{~m}^{-2}$; Sulfate: $-1.55 \pm 0.16$ to $2.14 \pm 0.17 \mathrm{~W} \mathrm{~m}^{-2}$ ) and surface (OC: $-0.49 \pm 0.31$ to $-2.56 \pm 0.45 \mathrm{~W} \mathrm{~m}^{-2}$, Sulfate: $-1.19 \pm 0.24$ to $2.67 \pm 0.36 \mathrm{~W} \mathrm{~m}^{-2}$ ) over the above regions (listed in Table-S1). Figures $4 \mathrm{~d}, 4 \mathrm{~g}$, and Fig. $4 \mathrm{j}$ further confirm our finding that the positive anomalies of radiative forcing in the IndoGangetic plain are due to $\mathrm{BC}$ aerosols because of its absorbing property. All the aerosols produce in-atmospheric warming over the Indian region and the north Indian Ocean. The atmospheric warming over the Arabian Sea and Bay of Bengal is due to BC and OC aerosols with larger contributions by the $\mathrm{BC}$ aerosols. 

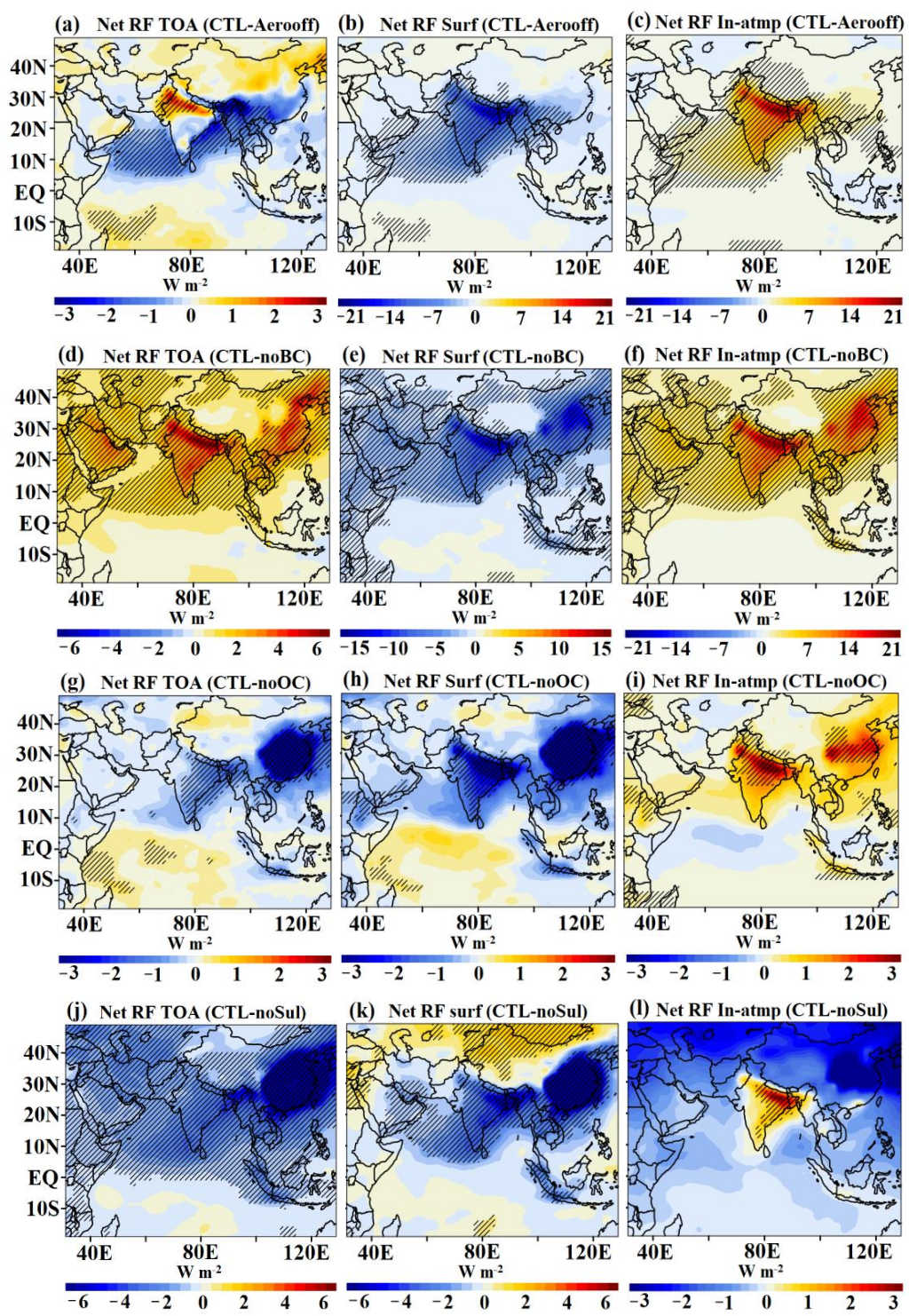

Figure 4: Spatial distribution of net aerosol radiative forcing (CTL - Aerooff) ( $\mathrm{W} \mathrm{m}^{-2}$ ) averaged for spring during 2001 - 2016 (a) TOA, (b) same as (a) but for surface, (c) same as (a) but for in-atmosphere (TOA - surface), (d) spatial distribution of radiative forcing at the TOA (CTL - BCoff) averaged for spring during 2001 - 2016, (e) same as (d) but for surface, (f) same as (d) but for in-atmosphere (TOA - surface), (g) spatial distribution of radiative forcing at the TOA (CTL - OCoff) averaged for spring during 2001 - 2016, (h) same as (g) but for surface, (i) same as (h) but for in-atmosphere (TOA - surface), (j) spatial distribution of radiative forcing at the TOA (CTL - Suloff) averaged for spring during 2001 - 2016, (k) same as (j) but for surface, (l) same as (k) but for in-atmosphere (TOA - surface). The hatched lines in figure a-1 indicate $99 \%$ confidence level for the 313 mean differences. 


\subsection{Transport of Asian anthropogenic aerosols into the UTLS}

Further, we investigate the vertical distribution of aerosols that are transported to the north Indian Ocean. Meridional sections over the Arabian Sea $\left(60-75^{\circ}\right.$ E) and Bay-of-Bengal (75 $-95^{\circ} \mathrm{E}$ ) for $\mathrm{BC}, \mathrm{OC}$, and sulfate aerosol anomalies indicate that these aerosols are transported from the boundary layer of both regions and north India into the UTLS (Figure 5 and Fig. S1). The spring convection occurring over the Arabian Sea and Bay-of-Bengal which is shown by the combined distribution of CDNC and ICNC (Fig. S2a) plays an important role in the vertical transport. The prevailing spring convection is further invigorated over the Arabian Sea by the transported aerosols there which is not the case for the Bay of Bengal region (Fig. S2b). The aerosol loading over the North-Indian region forms clouds and elicit convection there (Fig. S2c-d). The distribution of wind resolved circulation shows a strong ascent over the Arabian Sea, and the Bay-of-Bengal regions, while the steep orography of the Himalayas over North India also plays an important role in the vertical transport to the upper troposphere (Fig. 5 and Fig. S1). Figure 5 also shows that aerosols induce a secondary circulation, ascending winds over $10-30^{\circ} \mathrm{N}$ and descent over $30-40^{\circ}$ S. BC, OC, and sulfate aerosols are transported to the UTLS, moving southward and downward $\sim 30-40^{\circ} \mathrm{S}$ (Fig. 5a-f, and Fig. S1) due to this secondary circulation. The aerosol enhancement in the lower troposphere $(1000-500 \mathrm{hPa})$ over $30-40^{\circ} \mathrm{S}$ is therefore due to the combined impact of horizontal transport and downward transport from the UTLS due to this secondary circulation. Further, in the UTLS these aerosols are transported globally. There is enhancement in the Arctic (BC: 0.6 to $1.5 \mathrm{ng} \mathrm{m}^{-3}$, OC: 0.4 to $7 \mathrm{ng} \mathrm{m}^{-3}$, Sulfate: 0.1 to $20 \mathrm{ng} \mathrm{m}^{-3}$ ) and Antarctic (BC: 0.6 to $3 \mathrm{ng} \mathrm{m}^{-3}$, OC: 1 to $5 \mathrm{ng} \mathrm{m}^{-3}$, Sulfate: 6 to $40 \mathrm{ng} \mathrm{m}^{-3}$ ) in the lower stratosphere $(180-90 \mathrm{hPa})$ (see Figure 5). Our analysis shows that transport to the Arctic and Antarctic occurs every year in the UTLS which causes heating in the lower stratosphere (see Section 3.4). 

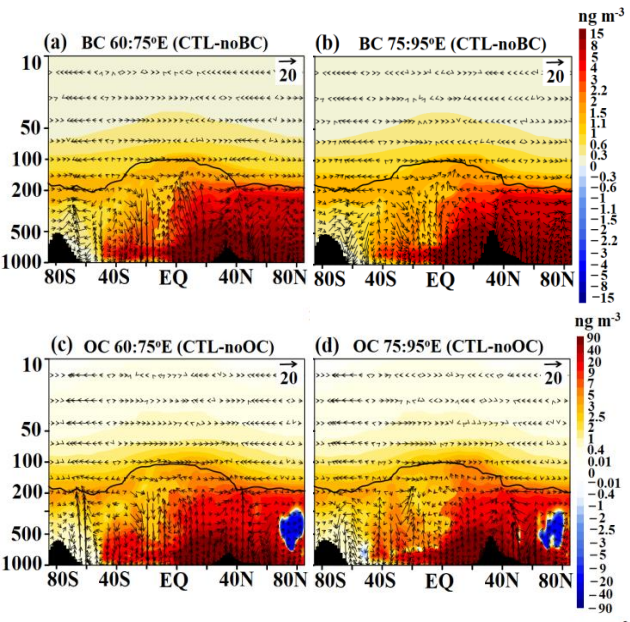
predominately scattering aerosols such as sulfate reflect and scatter back solar radiation, therefore cooling the atmosphere below (Fadnavis et al., 2019). The vertical distribution of heating rate anomalies induced by all the anthropogenic Asian aerosols (CTL - Aerooff) over the North Indian Ocean (Arabian Sea and North Bay of Bengal, $50-100^{\circ} \mathrm{E}$ ) indicates a significant increase in heating rates in the region of elevated anthropogenic aerosols in the troposphere $\left(0.05 \mathrm{~K} \mathrm{~d}^{-1}\right)$ and stratosphere $\left(0.002 \mathrm{~K} \mathrm{~d}^{-1}\right)$ (Fig. 6a-d, Fig. 5, and Fig. S1).

Figure 5: Meridional cross-section over Arabian Sea (averaged $60-75^{\circ}$ E) and Bay-ofBengal $\left(75-95^{\circ} \mathrm{E}\right)$ and for the spring season during $2001-2016$ of anomalies $\left(\mathrm{ng} \mathrm{m}^{-3}\right)$ of (a-b) BC aerosols (CTL-BCoff), (c-d) OC aerosols (CTL-OCoff), (e-f) sulfate aerosols (CTL-Suloff). Vectors in Figs. a-f indicate anomalies of winds $\left(\mathrm{m} \mathrm{s}^{-1}\right)$ (the vertical velocity field has been scaled by 300 and the units are $\mathrm{m} \mathrm{s}^{-1}$ ).

\subsection{Impacts on the heating rate and water vapor}

Carbonaceous aerosols absorb solar radiation, leading to atmospheric heating, while Heating rate anomalies estimated over the North Indian Ocean from BC (CTL - BCoff), OC 
(CTL - OCoff), and Sulfate (CTL - Suloff) show that BC and OC aerosols produce heating in the troposphere $\left(10-40^{\circ} \mathrm{N}\right)\left(\mathrm{BC}: 0.001\right.$ to $0.05 \mathrm{~K} \mathrm{~d}^{-1}$, OC: 0.0002 to $\left.0.02 \mathrm{~K} \mathrm{~d}^{-1}\right)$ and stratosphere $\left(100-50 \mathrm{hPa}, 90^{\circ} \mathrm{S}-90^{\circ} \mathrm{N}\right) \quad\left(\mathrm{BC}: 0.001\right.$ to $0.008 \mathrm{~K} \mathrm{~d}^{-1}$, OC: 0.0002 to $0.002 \mathrm{~K}$ $\mathrm{d}^{-1}$ ), while sulfate aerosols produce atmospheric cooling in the troposphere -0.001 to -0.05 (500 - tropopause) and stratosphere -0.001 to $-0.008 \mathrm{~K} \mathrm{~d}^{-1}$ (tropopause $-50 \mathrm{hPa}$ ) (Fig. 6a-d). There is anomalous heating in the tropical stratosphere $\left(20^{\circ} \mathrm{S}-20^{\circ} \mathrm{N}\right)\left(0.001\right.$ to $\left.0.002 \mathrm{~K} \mathrm{~d}^{-1}\right)$ seen in CTL-Aerooff simulations (Fig. 6a), mainly due to carbonaceous aerosols (Fig. 6b-c). carbonaceous aerosols lead to $0.002-0.01 \mathrm{~K} \mathrm{~d}^{-1}$ heating in the lower stratosphere globally $(100-50 \mathrm{hPa})$ (Fig. 6f-g), larger than the cooling induced by sulfate aerosols (Fig. 6h).

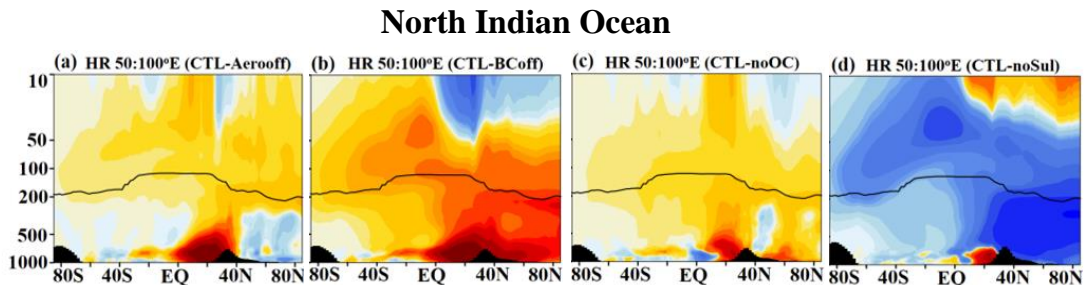

\section{Zonal mean}
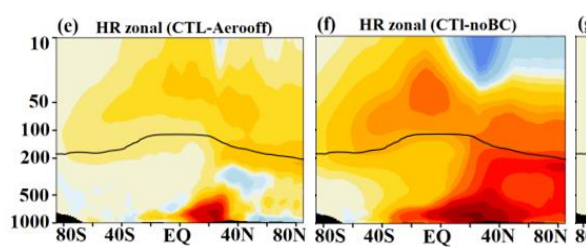

(g) HR zonal (CTL-noOC) (h) HR zonal (CTL-noSul)

Figure 6: Meridional cross-section over the North Indian Ocean (averaged over the Arabian Sea and Bay of Bengal region, $\left.50-100^{\circ} \mathrm{E}\right)$ of anomalies of heating rates $\left(\mathrm{K} \mathrm{d}^{-1}\right)$ averaged for the spring season during 2001 - 2016 (a) from CTL - Aerooff simulation, (b) same (a) but from CTL - BCoff simulation (c) same (a) but from CTL -OCoff simulation, (d) same (a) but from CTL - Suloff simulation. (e) Zonal mean $\left(0-360^{\circ}\right)$ anomalies in heating rate for CTL - Aerooff simulation, (f) same as (e) but from CTL - BCoff simulation, (g) same as (e) but from CTL - OCoff simulation, (h) same as (e) but from CTL - Suloff simulation. 
In general, these aerosols increase heating in the troposphere over the South Asian region (Fig. 6a) and northern Arabian Sea and Bay of Bengal $\left(10-30^{\circ} \mathrm{N}\right)$. This enhanced heating invigorates the convection process, which results in an increase in cloud cover (Fig. S2c) and deepening of the OLR (Fig. S2d). The invigorated convection provides positive feedback on the vertical ascent into the free troposphere that extends to above the tropopause into the lower stratosphere over the Arabian Sea and Bay-of-Bengal-North-India region (Fig. S3a-b) (Fadnavis et al., 2013; Randel et al., 2010).

The vertical distribution of water vapor over the Indian Ocean (CTL - Aerooff) shows that water vapor $(0-0.3 \mathrm{ppmv})$ is transported to the UTLS from the Arabian Sea $\left(55-70^{\circ} \mathrm{E}, 0-\right.$ $30^{\circ} \mathrm{N}$ ) (Fig. 7a) along the path of elevated aerosols (Fig. 5). Interestingly, there is an enhancement in water vapor over the southern Indian Ocean $\left(20-30^{\circ} \mathrm{S}, 55-70^{\circ} \mathrm{E}\right)$ along the path of the descending branch of aerosols (BC, OC, and sulfate). This is due to the significant heating caused by carbonaceous aerosols (Fig. 6b-c) which leads to enhancement of tropospheric water vapor (Fig. 7a) over the Arabian Sea. The zonal mean (averaged for $0-$ $\left.360^{\circ}\right)$ anomalies of water vapor (Fig. $\left.7 b\right)$ show an enhancement by $0.03-0.08$ ppmv (0-4\%) in the global stratosphere (Fig. 7b). There is an enhancement in the lower stratosphere in the Antarctic $\left(60-90^{\circ} \mathrm{S}\right)$ by 0.01 to $0.03 \mathrm{ppmv}$ and in the Arctic $\left(80-90^{\circ} \mathrm{N}\right)$ by $0.01-0.1 \mathrm{ppmv}$ caused by anthropogenic aerosols (CTL-Aerooff).

The impact of BC (CTL - BCoff), OC (CTL - OCoff), and Sulfate (CTL - Suloff) on water vapor distribution (Figs. $7 \mathrm{c}-\mathrm{f}$ ) shows that $\mathrm{BC}$ aerosols play a major role in water vapor enhancement in the stratosphere (Fig. $7 \mathrm{c}),(100-10 \mathrm{hPa})$. Water vapor enhancement by BC aerosols over the Arabian Sea region is $\sim 0.03-0.3 \mathrm{ppmv}$ (Fig. 7c) and $0.01-0.2 \mathrm{ppmv}$ in the global stratosphere (Fig. 7d). There is significant enhancement of water vapor due to BC aerosols in the Arctic $(0.01-0.2 \mathrm{ppmv})$ and Antarctic $(0.01-0.1 \mathrm{ppmv})$ (Fig. $7 \mathrm{~d})$. The water vapor enhancement by $\mathrm{OC}$ aerosols is negligible in the tropical stratosphere and there is no 

from the boundary layer to the mid-troposphere $(500 \mathrm{hPa})$, near the tropopause, and in the path of descending branch of secondary circulation over the South Indian Ocean $\left(\sim 20^{\circ} \mathrm{S}\right)$ (Fig. 7f).

Arabian Sea $55-70^{\circ} \mathrm{E} \quad$ Zonal mean $\left(0-360^{\circ}\right)$

(a) $\mathrm{H}_{2} \mathrm{O} 55: 70^{\circ} \mathrm{E}$ (CTL-Aerooff) (b) $\mathrm{H}_{2} \mathrm{O}$ zonal (CTL-Aerooff)
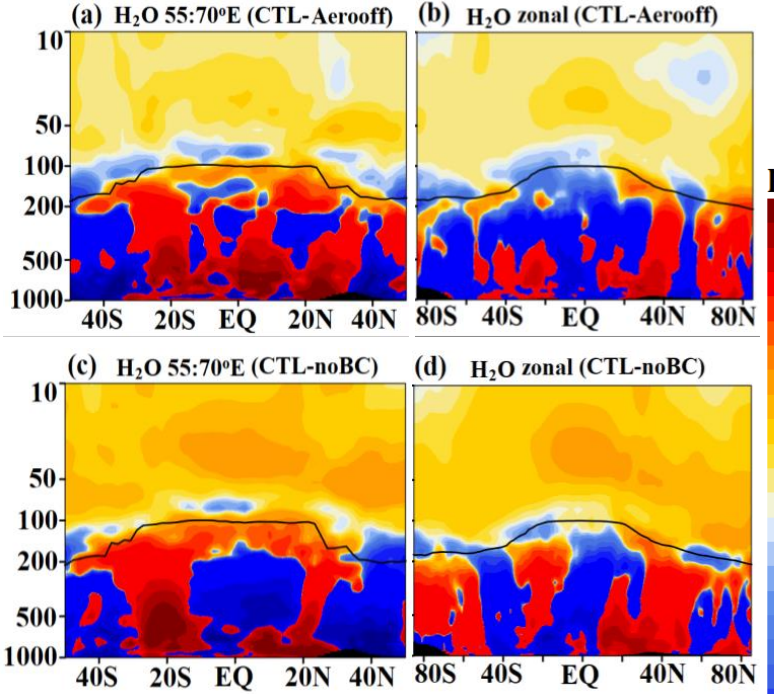

(d) $\mathrm{H}_{2} \mathrm{O}$ zonal (CTL-noBC)

\section{ppmv}

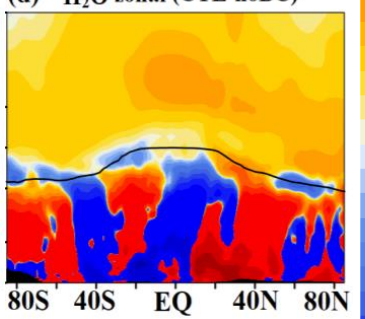

(e) $\mathrm{H}_{2} \mathrm{O} 55: 70^{\circ} \mathrm{E}$ (CTL-noOC)
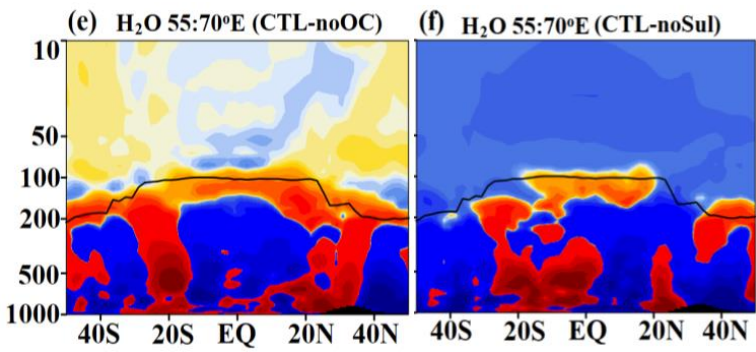

350

$\mathbf{1 5 0}$

Figure 7: (a) Meridional cross-section over Arabian Sea region (averaged $55-70^{\circ}$ E) of anomalies of water vapour (ppmv) (CTL - Aerooff) the for spring season during 2001 - 2016, (b) same as (a) but zonal mean (average for longitudes $0-360^{\circ}$ ), (c) same as (a) but from CTL - BCoff simulations, (d) same as (c) but zonal mean (average for longitudes $0-360^{\circ}$ ), (e) same as (a) but from CTL - OCoff simulations, (f) same as (a) but from CTL - Suloff 437 simulations.

438 Although the focus of the manuscript is on transport of aerosols during the spring season, it should be noted that the anthropogenic South Asian aerosols are also transported to the UTLS 

anomalies of aerosols (average of $\mathrm{BC}$, $\mathrm{OC}$ and sulfate) show transport of aerosols into the UTLS during spring and monsoon season (April to September) from the Arabian Sea, Bayof-Bengal-North-India region (Fig. 8a). These aerosols enhance tropospheric heating thereby transporting elevated water vapour into the lower stratosphere (Fig. 8b). Injection of aerosols into the lower stratosphere occurs every year however there is interannual variability. We show the vertical distribution of aerosols for two normal years when there was no large scale ocean-atmosphere coupling phenomenon like El Niño southern oscillation or Indian Ocean Dipole (2008 and 2016) in Fig. S4a-b. It also shows transport of aerosols into the lower stratosphere during spring and monsoon seasons (March-September). The aerosol induced enhanced water vapour also shows enhancement in the lower stratosphere during the same time (Figs. S4c-d). In the lower stratosphere, these aerosols persist for a few months (Fig. 8a) thus their effect will be seen for an extended time.
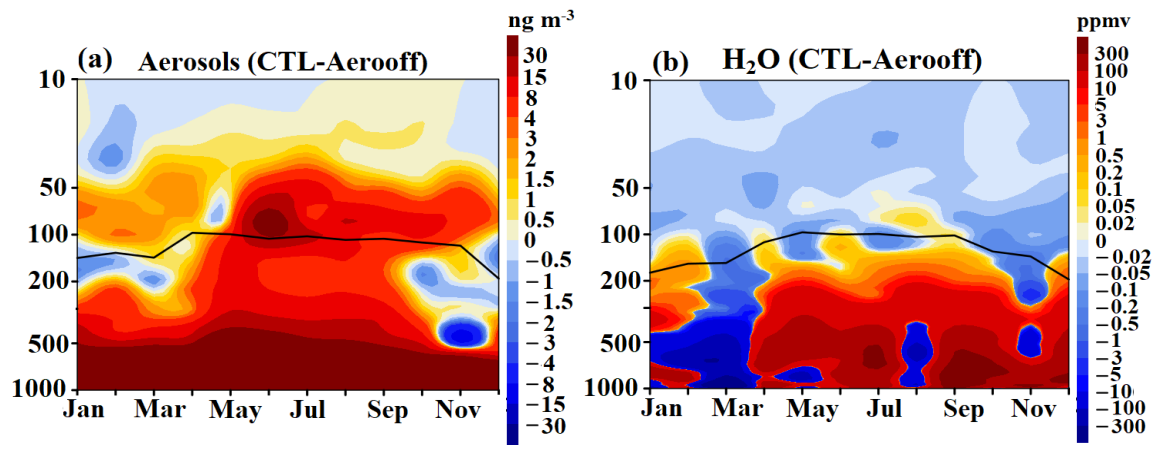

Figure 8: (a) Annual distribution of anomalies of aerosols (CTL - Aerooff) (averaged of BC, OC and sulfate aerosols) ( $\mathrm{ng} \mathrm{m}^{-3}$ ) averaged for Arabian Sea, Bay-of-Bengal-North-India region $\left(55-110^{\circ}\right.$ $\left.\mathrm{E}, 10-30^{\circ} \mathrm{N}\right)$ , (b) same as (a) (a) but for water vapour (ppmv).

Further, we analyze the correlation between heating rates and carbonaceous aerosol amounts in the UTLS (180 - $70 \mathrm{hPa})$ in the Arctic and Antarctic during 2001 - 2016 (spring mean) (Fig. 9) from Aerooff, BCoff, and OCoff in comparison with CTL simulations. The 

UTLS.

(a) Antarctic (CTL-noBC)
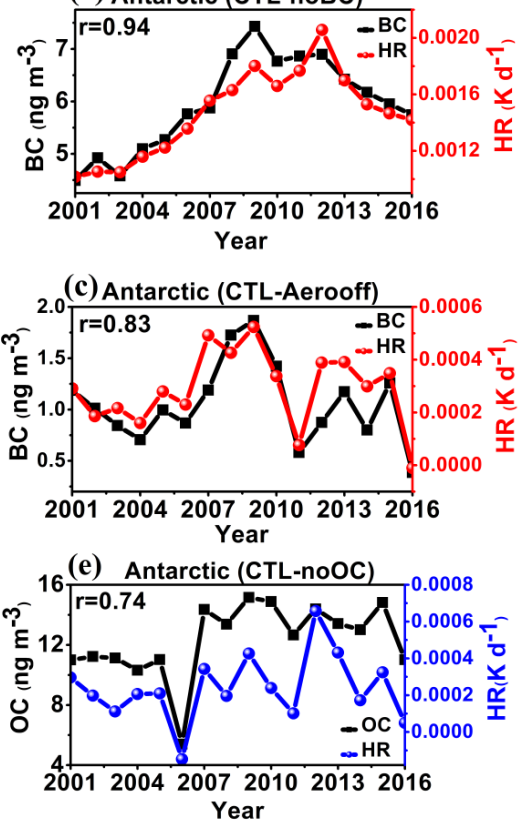

(g) Antarctic (CTL-Aerooff)

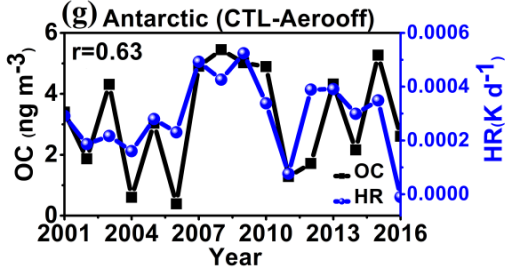

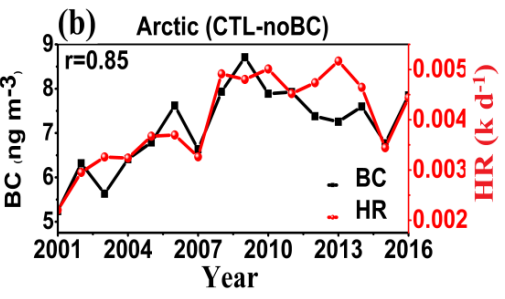

(d) Arctic (CTL-Aerooff)
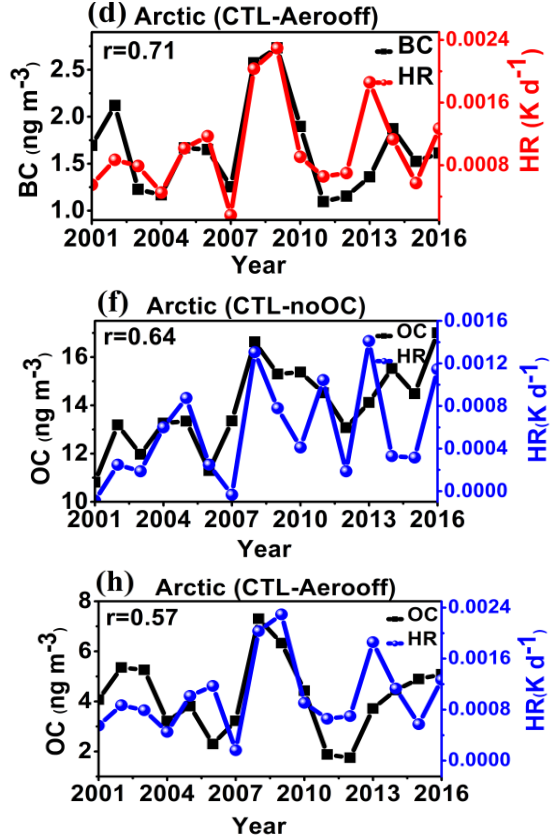

Figure 9: (a) Time series of $\mathrm{BC}$ aerosols and heating rates averaged for spring and UTLS $(180-70 \mathrm{hPa})$ at the Antarctic $\left(60-90^{\circ} \mathrm{S}, 0-360^{\circ}\right)$ (from CTL - BCoff, (b) same as (a) but in the Arctic $\left(65-85^{\circ} \mathrm{N}, 0-360^{\circ}\right)$, (c) same as (a) but from CTL - Aerooff, (d) same as (b) but from CTL - Aerooff, (e) same as (a) but for OC (CTL - OCoff), (f) same as (b) but for OC (CTL - OCoff), (g) same as (c) but for OC, (h) same as (d) but for OC. The correlation coefficient ( $\mathrm{r}$ ) between anomalies of $\mathrm{BC} / \mathrm{OC}$ aerosols and heating rates is indicated in panels a-h. 
Importantly, South Asian aerosols enhance water vapor in the lower stratosphere, globally. Water vapor being a greenhouse gas further enhances the heating of the troposphere leading to a positive feedback. The increase in water vapor in the stratosphere also warms the Earth's surface (Shindell, 2001; Solomon et al., 2010). Solomon et al. (2010) estimated that an increase in the stratospheric water vapor by $1 \mathrm{ppmv}$ accounts for $0.24 \mathrm{~W} \mathrm{~m}^{-2}$ radiative forcing. The SABER and MLS observations showed an increase in stratospheric water vapor by 0.45 ppmv globally during $2003-2017$ (Yue et al., 2019). Thus the radiative forcing due to water vapor increase $(0.02-0.14 \mathrm{ppmv})$ in response to South Asian anthropogenic aerosols is not negligible for surface warming globally. Further, increasing stratospheric water vapour could also lead to ozone depletion (e.g., Shindell, 2001, Robrecht et al., 2019).

\section{Conclusions}

A series of ECHAM6-HAMMOZ chemistry-climate simulations for South Asian anthropogenic aerosols were used to understand the transport pathways of Asian aerosols and their associated impacts. The analysis is performed for the spring season, when emissions of anthropogenic aerosols (BC, OC, and sulfate) over south Asia peak. The model simulations show that large amounts of South Asian aerosols are transported during spring to the Arabian Sea (increases in AOD by: $0.02-0.12$ from CTL - Aero0ff) and Bay of Bengal (increases in AOD by: 0.16 to 0.8 from CTL - Aerooff). The anthropogenic aerosols are further lifted up into the UTLS from the Arabian Sea and Bay-of-Bengal-North-India. In the UTLS, they are also transported to the southern hemisphere $\left(30-40^{\circ} \mathrm{S}\right)$ and downward in the troposphere by the secondary circulation induced by the aerosol changes. In the UTLS, these aerosols (BC, OC, and Sulfate) are transported globally.

511 The anthropogenic aerosol produces significant radiative impacts over the Indo-Gangetic

512 Plain (RF anomalies estimated from CTL-Aerooff simulations, TOA: $+1.27 \pm 0.16 \mathrm{~W} \mathrm{~m}^{-2}$, 
513 Surface: $-11.16 \pm 0.50 \mathrm{~W} \mathrm{~m}^{-2}$, In-atmosphere: $+12.44 \pm 0.42 \mathrm{~W} \mathrm{~m}^{-2}$ ) and the Arabian Sea (RF at the TOA: $-0.72 \pm 0.14 \mathrm{~W} \mathrm{~m}^{-2}$, surface: $-3.00 \pm 0.28 \mathrm{~W} \mathrm{~m}^{-2}$, In-atmosphere: $+2.27 \pm 0.19 \mathrm{~W} \mathrm{~m}^{-2}$ ).

515 Interestingly, $\mathrm{RF}$ at the TOA over the Indo-Gangetic Plain is positive $+4.33 \pm 0.17 \mathrm{~W} \mathrm{~m}^{-2}$ due 516 to the emission of $\mathrm{BC}$ aerosols. The anthropogenic aerosols enhance heating in the troposphere (estimated from CTL-Aerooff) by 0.002 to $0.05 \mathrm{~K} \mathrm{~d}^{-1}$ and UTLS by 0.001 to

$5180.002 \mathrm{~K} \mathrm{~d}^{-1}$ leading to more cloud formation (cloud cover anomalies enhanced by 2 to $12 \%$ )

519 and intensification of convection (OLR anomalies -0.5 to $-10 \mathrm{~W} \mathrm{~m}^{-2}$ ). This invigorated convection provides a positive feedback on the vertical updraft of aerosols into the free troposphere and above the tropopause into the lower stratosphere (Fadnavis et al., 2013; Randel et al., 2010). The tropospheric heating/cooling caused by the anthropogenic aerosols over South Asia and the North Indian Ocean during spring has implications on the Indian summer monsoon rainfall a few months later (Fadnavis et al., 2017a; Fadnavis and Chattopadhyay, 2017).

The heating of the troposphere by the carbonaceous aerosol increases evaporation and thereby tropospheric water vapor amounts over the North Indian Ocean and adjoining regions. The elevated water vapor is transported from highly convective regions (i.e. Arabian Sea) to the UTLS, from where it is then transported globally. BC aerosols play a major role in water vapor enhancement in the lower stratosphere, globally (increased water vapor by 0.01 to $0.1 \mathrm{ppmv})$. Water vapor being a greenhouse gas further enhances the heating of the troposphere leading to a positive feedback. The increase in water vapor in the stratosphere also warms the Earth's surface (Shindell, 2001; Solomon et al., 2010). in the Indian Institute of Tropical Meteorology, Pune, India, Pune, India. 
537 Data availability: The data used in this study are generated from ECHAM6-HAMMOZ 538 model simulations at the High-performance computing system in the Indian Institute of 539 Tropical Meteorology, Pune, India. The AOD data from MODIS Terra used here can be 540 downloaded from https://ladsweb.modaps.eosdis.nasa.gov/archive/allData/61/MODATML2/, 541 and MISR from https://misr.jpl.nasa.gov/getData/accessData/.

544 Author contributions: S. F. initiated the idea. A. J., S. S., A. A., performed model analysis. 545 R. M., and A. R. contributed to analysis and study design. All authors contributed to the 546 writing and discussions of the manuscript.

548 Competing Interests: Some authors are members of the editorial board of Atmospheric

549 Chemistry and Physics. The peer-review process was guided by an independent editor, and 550 the authors have also no other competing interests to declare. 


\section{References:}

Aswini, A. R., Hegde, P., Aryasree, S., Girach, I. A. and Nair, P. R.: Continental outflow of anthropogenic aerosols over Arabian Sea and Indian Ocean during wintertime: ICARB2018 campaign, Sci. Total Environ., 712, 135214, doi:10.1016/j.scitotenv.2019.135214, 2020.

Babu, S. S., Manoj, M. R., Moorthy, K. K., Gogoi, M. M., Nair, V. S., Kompalli, S. K., Satheesh, S. K., Niranjan, K., Ramagopal, K., Bhuyan, P. K. and Singh, D.: Trends in aerosol optical depth over Indian region: Potential causes and impact indicators, J. Geophys. Res. Atmos., 118, 11,794-11,806, doi:10.1002/2013JD020507, 2013.

Bibi H., Alam K., Chishtie F., Bibi S., Shahid I, Blaschke T., Intercomparison of MODIS, MISR, OMI, and CALIPSO aerosol optical depth retrievals for four locations on the Indo-Gangetic plains and validation against AERONET data, Atmospheric Environment, 111, 113-126, https://doi.org/10.1016/j.atmosenv.2015.04.013, 2015.

Budhavant, K., Bikkina, S., Andersson, A., Asmi, E., Backman, J., Kesti, J., Zahid, H., Satheesh, S. K. and Gustafsson, Ö.: Anthropogenic fine aerosols dominate the wintertime regime over the northern Indian Ocean, Tellus, Ser. B Chem. Phys. Meteorol., 70, 1-15, doi:10.1080/16000889.2018.1464871, 2018.

Chavan, P., Fadnavis, S., Chakroborty, T., Sioris, C. E. and Müller, R.: The outflow of Asian biomass burning carbonaceous aerosol into the UTLS in spring: Radiative effects seen in a global model, 21, 14371-14384, https://doi.org/10.5194/acp-2021-494, 2021.

Corrigan, C. E., Roberts, G. C., Ramana, M. V., Kim, D. and Ramanathan, V.: Capturing vertical profiles of aerosols and black carbon over the Indian Ocean using autonomous unmanned aerial vehicles, Atmos. Chem. Phys., 8, 737-747, doi:10.5194/acp-8-737$2008,2008$. 
Collins, M., Sutherland, M., Bouwer, L., Cheong, S.-M., Frölicher, T. L., Jacot Des Combes, H., Roxy, M. K., Losada, I., McInnes, K. L., Ratter, B., Rivera-Arriaga, E., Susanto, R. D., Swingedouw, D., Tibig, L., Bakker, P., Eakin, C. M., Emanuel, K., Grose, M., Hemer, M., Jackson, L., Kääb, A., Kajtar, J. B., Knutson, T., Laufkötter, C., Noy, I., Payne, M., Ranasinghe, R., Sgubin, G. and Timmermans, M.-L.: Extremes, Abrupt Changes and Managing Risks, IPCC Spec. Rep. Ocean Cryosph. a Chang. Clim., 589$655,2019$.

De Reus, M., Krejci, R., Williams, J., Fischer, H., Scheele, R. and Ström, J.: Vertical and horizontal distributions of the aerosol number concentration and size distribution over the northern Indian Ocean, J. Geophys. Res. Atmos., 106, 28629-28641, doi:10.1029/2001JD900017, 2001.

Dickerson, R. R., Andreae, M. O., Campos, T., Mayol-Bracero, O. L., Neusuess, C. and Streets, D. G.: Analysis of black carbon and carbon monoxide observed over the Indian Ocean: Implications for emissions and photochemistry, J. Geophys. Res. Atmos., 107, doi:10.1029/2001JD000501, 2002.

Diner, D. J., Abdou, W. A., Ackerman, T. P., Crean, K., Gordon, H. R., Kahn, R. A., Martonchik, J. V., Mcmuldroch, S., Paradise, S. R., Pinty, B., Verstraete, M. M., Wang, M., West, R. A. Level 2 aerosol retrieval algorithm theoretical basis, Jet Propuls. Lab. Intern. Doc. JPL D-11400, Rev C, 2008.

Fadnavis, S., Kalita, G., Rowlinson, M., Rap, A., Li, J.-L. F., Gasparini, B., Laakso, A. and Müller, R.: The impact of increases in South Asian anthropogenic emissions of $\mathrm{SO}_{2}$ on sulfate loading in the upper troposphere and lower stratosphere during the monsoon season and the associated radiative changes, Atmos. Chem. Phys., 19, 9989-10008, https://doi.org/10.5194/acp-19-9989-2019, 2019.

Fadnavis, S., Roy, C., Chattopadhyay, R., Sioris, C. E., Rap, A., Müller, R., Kumar, K. R. 

and Krishnan, R.: Transport of Asian trace gases via eddy shedding from the Asian summer monsoon anticyclone and associated impacts on ozone heating rates, Atmos. Chem. Phys., 18, 11493-11506, doi:10.5194/ acp-18-11493-2018, 2018.

Fadnavis, S., Roy, C., Sabin, T. P., Ayantika, D. C. and Ashok, K.: Potential modulations of pre-monsoon aerosols during El Niño: impact on Indian summer monsoon, Clim. Dyn., 49, 2279-2290, doi:10.1007/s00382-016-3451-6, 2017a.

Fadnavis, S., Kalita, G., Ravi Kumar, K., Gasparini, B. and Li, J. L. F.: Potential impact of carbonaceous aerosol on the upper troposphere and lower stratosphere (UTLS) and precipitation during Asian summer monsoon in a global model simulation, Atmos.

Fadnavis, S. and Chattopadhyay, R.: Linkages of subtropical stratospheric intraseasonal intrusions with Indian summer monsoon deficit rainfall, J. Clim., 30, 5083-5095, doi:10.1175/JCLI-D-16-0463.1, 2017.

Fadnavis S., Semeniuk K., Schultz M.G., Kiefer M., Mahajan A., Pozzoli L., Sonbawane S., Transport pathways of peroxyacetyl nitrate in the upper troposphere and lower stratosphere from different monsoon systems during the summer monsoon season, Atmospheric Chemistry and Physics, 15, 11477-11499, DOI:10.5194/acp-15-11477$2015,2015$.

Fadnavis S., Schultz M.G., Semeniuk K., Mahajan A.S., Pozzoli L., Sonbawane S., Ghude S.D., Kiefer M., Eckert E., Trends in Peroxyacetyl Nitrate (PAN) in the upper troposphere and lower stratosphere over Southern Asia during the summer monsoon season: regional impacts., Atmospheric Chemistry and Physics, 14, 12725-12743, DOI:10.5194/acp-14-12725-2014, 2014. 

doi:10.5194/acp-13-8771-2013, 2013.

Fadnavis, S., Sioris, C. E., Wagh, N., Chattopadhyay, R., Tao, M., Chavan, P. and Chakroborty, T.: A rising trend of double tropopauses over South Asia in a warming environment: Implications for moistening of the lower stratosphere, Int. J. Climatol., 41, E200-E215, doi:10.1002/joc.6677, 2020.

Fadnavis, S., Sabin, T. P., Rap, A., Müller, R., Kubin, A. and Heinold, B.: The impact of COVID-19 lockdown measures on the Indian summer monsoon, Environ. Res. Lett., 16, 074054, doi:10.1088/1748-9326/ac109c, 2021a.

Fadnavis S., Müller R , Chakraborty T. , Sabin T. P., Laakso A. , Rap A., Griessbach S., Vernier J-P., and Tilmes S., The role of tropical volcanic eruptions in exacerbating Indian droughts, Sci. Rep., 11, 2714, doi.org/10.1038/s41598-021-81566-0, 2021b.

Gogoi, M. M., Tandule, C. R., Jayachandran, V., Kompalli, S. K., Nair, V. S., Gopal, K. R. and Babu, S. S.: Spatial gradient of aerosol mass concentrations and size distributions over southeastern Arabian Sea and equatorial Indian Ocean during ICARB-2018, Atmos. Environ., 213, 727-738, doi:10.1016/j.atmosenv.2019.06.038, 2019.

Jose, S., Nair, V. S. and Babu, S. S.: Anthropogenic emissions from South Asia reverses the aerosol indirect effect over the northern Indian Ocean, Sci. Rep., 10, 18360, doi:10.1038/s41598-020-74897-x, 2020.

Karambelas, A., Holloway, T., Kinney, P. L., Fiore, A. M., Defries, R., Kiesewetter, G. and Heyes, C.: Urban versus rural health impacts attributable to PM2.5 and O3 in northern India, Environ. Res. Lett., 13, 064010, doi:10.1088/1748-9326/aac24d, 2018.

Lu, Z., Zhang, Q. and Streets, D. G.: Sulfur dioxide and primary carbonaceous aerosol 

doi:10.5194/acp-11-9839-2011, 2011.

Mahowald, N. M., Hamilton, D. S., Mackey, K. R. M., Moore, J. K., Baker, A. R., Scanza, R. A. and Zhang, Y.: Aerosol trace metal leaching and impacts on marine microorganisms, Nat. Commun., 9, 2614, doi:10.1038/s41467-018-04970-7, 2018.

Mhawish, A. T., Banerjee, M., Sorek-Hamer, A., Lyapustin, D., Broday, and Chatfield, R.: Comparison and Evaluation of MODIS Multi-Angle Implementation of Atmospheric Correction (MAIAC) Aerosol Product over South Asia, Remote Sens. of Environ., 224, $12-28,2019$.

Mayol-Bracero, O. L., Gabriel, R., Andreae, M. O., Kirchstetter, T. W., Novakov, T., Ogren, J., Sheridan, P. and Streets, D. G.: Carbonaceous aerosols over the Indian Ocean during the Indian Ocean Experiment (INDOEX): Chemical characterization, optical properties, and probable sources, J. Geophys. Res. Atmos., 107, 8030, doi:10.1029/2000JD000039, 2002.

McFarquhar, G. M. and Wang, H.: Effects of aerosols on trade wind cumuli over the Indian Ocean: Model simulations, Q. J. R. Meteorol. Soc., 132, 821-843, doi:10.1256/qj.04.179, 2006.

Meehl, G. A., Arblaster, J. M. and Collins, W. D.: Effects of black carbon aerosols on the Indian monsoon, J. Clim., 21, 2869-2882, doi:10.1175/2007JCLI1777.1, 2008.

Nair, V. S., Babu, S. S., Manoj, M. R., Moorthy, K. K. and Chin, M.: Direct radiative effects of aerosols over South Asia from observations and modeling, Clim. Dyn., 49, 14111428, doi:10.1007/s00382-016-3384-0, 2017.

Neubauer, D., Lohmann, U., Hoose, C. and Frontoso, M. G.: Impact of the representation of marine stratocumulus clouds on the anthropogenic aerosol effect, Atmos. Chem. Phys., 
Paliwal, U., Sharma, M. and Burkhart, J. F.: Monthly and spatially resolved black carbon emission inventory of India: Uncertainty analysis, Atmos. Chem. Phys., 16, 1245712476, doi:10.5194/acp-16-12457-2016, 2016.

Papaspiropoulos, G., Martinsson, B. G., Zahn, A., Brenninkmeijer, C. A. M., Hermann, M., Heintzenberg, J., Fischer, H. and Van Velthoven, P. F. J.: Aerosol elemental concentrations in the tropopause region from intercontinental flights with the Civil Aircraft for Regular Investigation of the Atmosphere Based on an Instrument Container (CARIBIC) platform, J. Geophys. Res. Atmos., 107, 4671, doi:10.1029/2002JD002344, 2002.

Pathak, H. S., Satheesh, S. K., Moorthy, K. K. and Nanjundiah, R. S.: Assessment of regional aerosol radiative effects under the SWAAMI campaign - Part 2: Clear-sky direct shortwave radiative forcing using multi-year assimilated data over the Indian subcontinent, Atmos. Chem. Phys., 20, 14237-14252, doi:10.5194/acp-20-14237-2020, 2020 .

Penner, J. E., Chuang, C. C. and Grant, K.: Climate forcing by carbonaceous and sulfate aerosols, Clim. Dyn., 14, 839-851, doi:10.1007/s003820050259, 1998.

Rajeev, K. and Ramanathan, V.: Direct observations of clear-sky aerosol radiative forcing from space during the Indian Ocean Experiment, J. Geophys. Res. Atmos., 106, 1722117235, doi:10.1029/2000JD900723, 2001.

Ramachandran, S., Rupakheti, M. and Lawrence, M. G.: Aerosol-induced atmospheric heating rate decreases over South and East Asia as a result of changing content and composition, Sci. Rep., 10, 20091, doi:10.1038/s41598-020-76936-z, 2020a. 
Ramachandran, S., Rupakheti, M. and Lawrence, M. G.: Black carbon dominates the aerosol absorption over the Indo-Gangetic Plain and the Himalayan foothills, Environ. Int., 142, 105814, doi:10.1016/j.envint.2020.105814, 2020 b.

Ramanathan, V., Chung, C., Kim, D., Bettge, T., Buja, L., Kiehl, J. T., Washington, W. M., Fu, Q., Sikka, D. R. and Wild, M.: Atmospheric brown clouds: Impacts on South Asian climate and hydrological cycle, Proc. Natl. Acad. Sci. U. S. A., 102, 5326-5333, doi:10.1073/pnas.0500656102, 2005.

Ramanathan, V., Crutzen, P. J., Lelieveld, J., Mitra, A. P., Althausen, D., Anderson, J., Andreae, M. O., Cantrell, W., Cass, G. R., Chung, C. E., Clarke, A. D., Coakley, J. A., Collins, W. D., Conant, W. C., Dulac, F., Heintzenberg, J., Heymsfield, A. J., Holben, B., Howell, S., Hudson, J., Jayaraman, A., Kiehl, J. T., Krishnamurti, T. N., Lubin, D., McFarquhar, G., Novakov, T., Ogren, J. A., Podgorny, I. A., Prather, K., Priestley, K., Prospero, J. M., Quinn, P. K., Rajeev, K., Rasch, P., Rupert, S., Sadourny, R., Satheesh, S. K., Shaw, G. E., Sheridan, P. and Valero, F. P. J.: Indian Ocean Experiment: An integrated analysis of the climate forcing and effects of the great Indo-Asian haze, J. Geophys. Res. Atmos., 106, 28371-28398, doi:10.1029/2001JD900133, 2001.

Randel, W. J., Park, M., Emmons, L., Kinnison, D., Bernath, P., Walker, K. A., Boone, C. and Pumphrey, H.: Asian monsoon transport of pollution to the stratosphere, Science, 328, 611-613, doi:10.1126/science.1182274, 2010

Reddy, M. S., Boucher, O., Venkataraman, C., Verma, S., Léon, J. F., Bellouin, N. and Pham, M.: General circulation model estimates of aerosol transport and radiative forcing during the Indian Ocean Experiment, J. Geophys. Res., 109, D16205, doi:10.1029/2004JD004557, 2004.

Robrecht, S., Vogel, B., Grooß, J.-U., Rosenlof, K., Thornberry, T., Rollins, A., Krämer, M., 

conditions in the mid-latitude lower stratosphere in summer, Atmos. Chem. Phys., 19, 5805-5833, doi:10.5194/acp-19-5805-2019, 2019.

Romatschke, U. and Houze, R. A.: Characteristics of precipitating convective systems in the South Asian monsoon, J. Hydrometeorol., 12, 3-26, doi:10.1175/2010JHM1289.1,

Satheesh, S. K., Ramanathan, V., Holben, B. N., Krishna Moorthy, K., Loeb, N. G., Mating, H., Prospero, J. M. and Savoie, D.: Chemical, microphysical, and radiative effects of

Satheesh, S. K. and Ramanathan, V.: Large differences in tropical aerosol forcing at the top of the atmosphere and Earth's surface, Nature, 405, 60-63, doi:10.1038/35011039,

Shindell, D. T.: Climate and ozone response to increased stratospheric water vapor, Geophys.

Solomon, S., Rosenlof, K. H., Portmann, R. W., Daniel, J. S., Davis, S. M., Sanford, T. J. and

Stier, P., Feichter, J., Kinne, S., Kloster, S., Vignati, E., Wilson, J., Ganzeveld, L., Tegen, I.,

Taylor, K. E., Williamson, D. L. and Zwiers, F. W.: The Sea Surface Temperature and SeaIce Concentration Boundary Conditions for AMIP II Simulations, Program for Climate 

2000.

Tegen, I., Neubauer, D., Ferrachat, S., Drian, C. S. Le, Bey, I., Schutgens, N., Stier, P., Watson-Parris, D., Stanelle, T., Schmidt, H., Rast, S., Kokkola, H., Schultz, M., Schroeder, S., Daskalakis, N., Barthel, S., Heinold, B. and Lohmann, U.: The global aerosol-climate model echam6.3-ham2.3 -Part 1: Aerosol evaluation, Geosci. Model Dev., 12, 1643-1677, doi:10.5194/gmd-12-1643-2019, 2019.

Tegen, I., Harrison, S. P., Kohfeld, K. E., Prentice, I. C., Coe, M., and Heimann, M.: Impact of vegetation and preferential source areas on global dust aerosol: Results from a model study, J. Geophys. Res.-Atmos., 107, 14-27, https://doi.org/10.1029/2001JD000963, 2002.

Yue, J., Russell, J., Gan, Q., Wang, T., Rong, P., Garcia, R. and Mlynczak, M.: Increasing Water Vapor in the Stratosphere and Mesosphere After 2002, Geophys. Res. Lett., 46, 13452-13460, doi:10.1029/2019GL084973, 2019.

Zhang, K., O’Donnell, D., Kazil, J., Stier, P., Kinne, S., Lohmann, U., Ferrachat, S., Croft, B., Quaas, J., Wan, H., Rast, S. and Feichter, J.: The global aerosol-climate model ECHAM-HAM, version 2: Sensitivity to improvements in process representations, Atmos. Chem. Phys., 12, 8911-8949, doi:10.5194/acp-12-8911-2012, 2012. 